\title{
TEMBLORES DOCUMENTADOS PARA EL PERIODO COLONIAL DE COSTA RICA
}

\author{
*Giovanni Peraldo Huertas \& Walter Montero Pohly \\ Escuela Centroamericana de Geología, Apto. 214-2060 Universidad de Costa Rica \\ *Autor de contacto: gperaldo@geología.ucr.ac.cr
}

(Recibido: 24/10/06; aceptado: 20/11/07)

\begin{abstract}
In the present article we transcribe a collection of documents of the Colonial period, that explicitly referred the occurrence of earthquakes in Costa Rica. They were partially included in Peraldo \& Montero (1994). The documents rescue interesting details of the historical circumstances when the earthquakes occurred, such as the social environment, costumes, administrative affairs, among others.
\end{abstract}

Key words: Seismology, History, Paleography, Colonial Age, Costa Rica.

RESUMEN: En el presente artículo se transcriben en forma completa una colección de documentos del periodo colonial, que explícitamente refieren la ocurrencia de temblores en Costa Rica. Estos fueron parcialmente incorporados en Peraldo \& Montero (1994). Los documentos rescatan detalles interesantes del entorno histórico cuando ocurrieron los sismos, como son el entorno social, costumbres, aspectos administrativos, entre otros.

Palabras claves: Sismología, Historia, Paleografía, Colonia, Costa Rica.

PERALDO, G. \& MONTERO, W., 2006: Temblores documentados para el período colonial de Costa Rica.- Rev. Geol. Amér. Central, 36 Especial: 25-47. 


\section{INTRODUCCIÓN}

En Costa Rica, la mayor cantidad de datos macrosísmicos sobre terremotos históricos proviene de información primaria y secundaria recopilada para los siglos XIX y XX. Además, en este último siglo se cuenta con bases instrumentales de datos sísmicos. Lo anterior, ha sido el resultado de una profusa investigación iniciada desde los años de 1980, para tratar de rescatar la mayor cantidad de documentos que sean evidencia primaria de la ocurrencia de sismos. Sin embargo, para el período colonial (1500-1821) la información recopilada sobre terremotos es muy escueta. Entre los estudios realizados para ese período destaca el de Peraldo \& Montero (1994), quienes analizan la sismicidad a partir de información obtenida en diversas fuentes, tales como son archivos, hemerotecas, publicaciones especializadas en historia y sismología, como la escrita por don Cleto González Víquez (1910). Como resultado de la anterior búsqueda documental, se aportó información nueva sobre ese periodo de la historia del país. Sin embargo, en Peraldo \& Montero (1994) no se transcribieron en forma completa las fuentes primarias de los terremotos ocurridos en el período colonial. Considerando lo anterior, en el presente artículo se transcribe la información primaria completa de los sismos recopilados en Peraldo \& Montero (1994), dado no solamente el interés sismológico que tienen, sino porque estos documentos aportan información sobre el contexto histórico de los terremotos y pueden ser fuente de interés para estudiosos de otras disciplinas.

\section{FUENTES DE INFORMACIÓN CONSULTADAS Y LIMITACIONES}

Las fuentes documentales usadas se recopilaron en el Archivo Nacional de Costa Rica, el Archivo Eclesiástico de la Curia Metropolitana de San José y el Archivo General de Centro América, este último ubicado en Ciudad Guatemala. En el Cuadro 1 se resumen los acervos documentales consultados para esta investigación.

Una de las limitaciones encontradas en el estudio de los sismos ocurridos en el periodo colonial, basados en fuentes documentales de archivos, es la escasa información existente para los siglos XVI al XVIII. Esto por diversas razones, tales como la escasa población y la poca densidad de los núcleos urbanos. Fue hasta la segunda mitad del siglo XVIII cuando se establecieron varias villas en el Valle Central, pues previamente la población era dispersa y la única población digna de llamársele así fue la ciudad de Cartago.

Otra limitación encontrada fue que los documentos no fueron conservados adecuadamente, en parte por la indolencia de los escribanos de la época por plasmar los hechos en documentos, en muchos casos porque estos puestos se compraban y en algunos casos porque la persona que protegía los libros era analfabeta. Al respecto es interesante y cómica la referencia sobre la causas para la destrucción de documentos por indolencia de los custodios de los archivos de la época. Ejemplo son las citas siguientes: .. por cuanto las yeguas se habían comido los libros...ó, ... porque una gallina rompió y desgarró las hojas en que se hallaba un original... (Aguilar, 1997). Esta última situación se presentó hasta principios del siglo XVIII.

Un problema adicional encontrado en el estudio sismológico del período colonial es que muchos documentos no tienen un adecuado estado de conservación, por lo que la humedad ha borrado y ampliado los trazos de la escritura, confundiendo esta con la de renglones contiguos. Este es el caso del documento primario que hace referencia al sismo de 1728 , documento que prácticamente es ilegible. Pero sea cual sea el motivo que haya originado la ausencia de información, el hecho es que se dificulta sobremanera el estudio de los sismos de la época colonial del país, dado que realmente son muy escasos los sismos documentados con fuentes primarias, a pesar de la importante sismicidad del país, donde los sismos destructivos se presentan con relativa frecuencia (entre años y unas pocas décadas).

La transcripción de los documentos que se realiza en este estudio es textual y respeta enteramente la forma de escritura y las palabras, tal como fueron escritas por el escribano. Esto tiene como objetivo acercar el texto original a lectores que no están acostumbrados a este tipo de "errores lexicográficos", que en múltiples ocasiones se convierten en verdaderos escollos para entender el sentido que el escribano quiso darle al discurso del documento. 


\section{TEMBLORES DEL PERIODO COLONIAL: DOCUMENTACIÓN EXPLÍCITA}

A continuación se transcriben los documentos que explícitamente refieren la ocurrencia de temblores durante la época colonial. Como se verá, los que son más ricos en información, son los que se escribieron al final de la época colonial.

\section{Temblores referidos en el año 1678}

Esta es la primera referencia de temblores a partir de información documental primaria, la cual fue ubicada en el Archivo Nacional de Costa Rica. Estos temblores afectaron el templo parroquial de la ciudad de Cartago, pero parece que los daños no tuvieron gran importancia, por lo que deja entrever el documento localizado.

"El alferez Estevan de Hozes Navarro, síndico general de los Religiosos [roto, se infiere por contenido: del Convento] de San Francisco, desta provincia de Costa Rica. En nombre de este Santo Conbento de Car[roto, se infiere por contenido: tago] y del muy reverendo Padre Fray Ambrosio [Salado] de Ordiales Padre y definidor habitual [roto] Presidente General de dicho convento, y comissario provincial de dicha provincia de Costa Rica.

Parezco como mejor convenga a su derecho ante su señoría del ilustre cavildo de dicha ciudad y digo:

Que por quanto el Padre Fray Manuel de San Gabriel religioso descalzo del horden de Nuestro Padre San Agustín vino a esta ciudad con pretexto de fundar convento de su religión en ella y aunque no manifestó los recados nessessarios y Licencia de su Majestad, le asignaron la hermita de San Nicolás, en el ínterin que traxessen dicha licencia, y lo demás nessesario para su fundación todo lo qual es en perjuicio deste Santo Convento, por lo estéril de la tierra; y estar este convento fundado juntamente con la ciudad, y no solo no tiene lo muy nessesario, pero i se halla amenazando ruina, como la iglesia, así por falta de medios, como por los accidentes que han sucedido de temblores, y un rayo y aunque se han procurado por todos los medios posibles su reparo, no se han podido conseguir, por lo atenuado $d[$ roto, se infiere por contexto: e los] caudales de los vecinos, como consta al presente pues abiendo caydo un [roto, se infiere por contexto: rayo] en la capilla mayor, que maltrató el retablo, las imágenes y el sagra[roto, se infiere por contexto: rio] mucha parte del altar y techo, habiendo salido a pedir alguna limosna para su remiendo y assistiendo a ello dos personas republicanas de esta ciudad con el convento apenas se pudieron juntar cantidad de diez y seis pesos en plata y géneros, por estas causas y por otras muchas que no refiero, y por el agrabio manifestó que éste Santo Convento se les sigue aumentándose limosneros. A su Vuestra Señoría pido y suplico = Sea servido de atender en nombre de su majestad a dichas causas, y no permitir que dicho padre funde convento en tan conocido agrabio, y detrimento deste y por quanto no tiene licencia en forma de su majestad como conviene, y de lo contrario, protesto de recurrir a algun acuerdo de justicia de la real chancillería de Guatemala y al consejo de Indias para cuyo efecto pido un tanto de esta petición, y lo proveydo [...] justicia lo qual pido y lo necesario. Estevan de Oses Navarro. 22 de mill seiscientos setenta y ocho años." (Archivo Nacional, Cartago, No. 1143, folio 10).

El lector no familiarizado con terminología colonial encontrará palabras que no puede entender sino se ubican en contexto histórico, entre ellas destacan, por ejemplo, alférez que era la persona que llevaba el estandarte real. Era un título de mucho prestigio en el cabildo y en el ejército. Cabildo fue un sinónimo de municipalidad y actualmente la palabra se sigue usando para designar una reunión municipal de toma de decisiones como cabildeo.

El daño relacionado con los temblores está circunscrito a la ciudad de Cartago. Sin embargo, no se les conoce el mes ni el año en que estos ocurrieron, aunque el documento es fechado en 1678. Por lo anterior, se infiere que los temblores ocurrieron en el año 1678, considerando datos adicionales aportados por González (1910), que no pudieron ser localizados en los archivos. También queda la incertidumbre, por información documental implícita y contenida en Peraldo \& Montero (1994), si no provocó daños en el puerto de La Caldera. Estos autores asignan intensidad MM VII en la ciudad de Cartago. Esta intensidad se sustenta en la información contenida en 
el documento reproducido en este trabajo y en la existente en documentos implícitos que refieren para el año 1679 que la ciudad de Cartago tenía necesidad de reparaciones generales, tanto en casas como en lo demás, por lo que se insta para que los reparos en las casas se hagan con la mayor rapidez posible, lo cual se puede interpretar como una situación de emergencia (Archivo Nacional, Cartago, No. 1143, f. 49; en: Peraldo \& Montero, 1994). Sin embargo, dada la parquedad en la descripción del evento y de los daños y la escasa documentación disponible, no se puede analizar más allá de asumir una posible intensidad.

Un aspecto histórico que destaca en el documento y que motivó la documentación del sismo, es la competencia que para los franciscanos significaba la fundación de un convento de una orden religiosa ajena a la de ellos. En el documento analizado se hace un reclamo contundente de los religiosos de la orden de San Francisco al establecimiento de otra orden en Cartago, para lo cual adujeron problemas meramente económicos. El reclamo es particularmente importante, porque en aras de perjudicar el establecimiento de la nueva orden, pudo ser que se sobrestimaran los daños asociados al terremoto y al rayo. Asimismo, se infiere del documento que los daños causados en el templo por el evento meteorológico fueron mayores al sísmico.

\section{Temblor de 1715}

Los datos macrosísmicos que han sido recuperados para este sismo, son más conspicuos que los asociados al sismo antecedente. La información corresponde nuevamente a la ciudad de Cartago y los daños están referidos al templo de los Ángeles en el barrio de los Naboríos.

"El Sargento Mayor Francisco de la Madríz Linares y el Capitán Blas de Ancheta, mayordomos de la Cofradía de Nuestra Señora de los Ángeles, los alfereses Juan Calderón y Juan Madríz, Joseph Batista, el ayudante Luys de Salazar, Diego Gómez y Pasqual Solano, diputados de dicha cofradía; y los demás hermanos que aquí firmamos; parecemos ante Vuestra Merced y decimos, que por el mes de enero próximo pasado deste presente año ubo un temblor con el qual quedó la iglesia de Nuestra Señora tan deteriorada que amenaza ruyna con peligro de que si se cae se pierdan maderas y teja; y se imposibilite de poderla volver a reedificar por los cortos medios que dicha cofradía tiene sobre que Vuestra Merced a de ser muy servido de pasar a hazer vista de ojos y reconocido el daño que tiene darnos la licencia que en tal caso necesitamos para pasar la imagen de Nuestra Señora y demás imágenes que en dicha iglesia hay; a la de nuestra Señora de la Soledad; y para que podamos desvaratar dicha iglesia, $y$ volverla a reedificar, y que así, para lo uno como para lo otro, nos podamos valer de los vienes o esquilmos que dicha cofradía tiene, en que pondremos el cuidado de que no quede destituida para en la de adelante; $y$ que si necesario sea Vuestra Merced se sirva de requerir a su Maestro; el Gobernador y Capitán General desta provincia, aga asimismo vista de dicha yglesia para que como cosa que es del servicio de Dios Nuestro Señor y aumento de su culto y veneración a María Santísima, Madre de Dios y señora y abogada nuestra, dé su Merced el abio que fuera necesario para la más breve conclusión de dicha fábrica, como también se nos concede lizencia para que así en los términos y jurisdicción desta ciudad como en las más partes que convengan, se pueda pedir y se pida limosna para ayuda de dicha fábrica por todo lo qual y lo más que ase y aser puede a favor de dicha cofradía y reparo de dicha iglesia [...] y veneración de María Santísima. A su Merced pido y suplico sea muy servido de abernos por presentado y provea y mande según el tenor deste escrito, pues en acerlo asi se aseguran los materiales de dicha iglesia, y el reparo de ella, y nosotros cumpliremos con dicha obligación y [...] muestra y para ello firmamos

Don Alfonso Guevara Don Pedro de Alvarado y Jirón Juan de la Madríz Linares Blas de Ancheta Lorenzo de Arburola y Irribaren Joseph de Chavarría Manuel Antonio de Arleguí Juan de Aguirre Mathias [...]" (Archivo Curia Metropolitana, Fondos Antiguos, documentos empastados, Libro de Cofradía de Nuestra Señora de los Ángeles).

Con relación al anterior documento se deben aclarar el significado de varios términos, que actualmente tienen un uso limitado: por ejemplo, 
la cofradía era una institución colonial laica de orden religiosa, que llegó en su momento a poseer una buena cantidad de bienes inmuebles y en moneda, de los cuales hacía préstamos incluso a los gobernadores de la provincia. Como toda organización, la cofradía tenía diferentes puestos administrativos como el de diputado, que es referido en el documento. Estos tenían una misión muy importante dentro de la cofradía, pues eran los que recolectaban los tributos de las filiales asociadas a ella.

Cuando en el documento se refiere al templo de "Nuestra Señora" describe al templo donde se venera a la Virgen de los Ángeles y se ubicó en el mismo sitio que actualmente tiene en la ciudad de Cartago.

Para solicitar la inspección de los daños ocurridos en el templo, se usa la frase "hacer vista de ojos", que para nuestros días es redundante, pero no para la época en que se redactó el documento. El otro término es el sentido que debe dársele a fábrica en el documento, como refiere la estructura material del edificio destinado en este caso al templo de Nuestra Señora de los Ángeles.

En el mismo libro en que se logró localizar el anterior documento, se encuentra este otro que también alude al terremoto de 1715:

"En la Ciudad de Cartago, en primer día del mes de abril de este presente año de 1715 en acto de visita su Merced el licenciado don Manuel Jiménez dean cura interino del valle de Nicaragua Vicario, juez eclesiástico en él y la jurisdicción de Nicoya; examinador sinodal y visitador general de este obispo de Nicaragua y Costarrica por el Ilustrísimo y Reverendísimo señor nuestro Don Fray Benito Garret y Arloví, dignísimo señor obispo del consejo de su majestad y su predicación. Passó al sittio donde está edificada la hermita de Nuestra Señora de los Ángeles en compañía del Beneficiado don Diego de Angulo y Gascón, cura propio en dicha ciudad y de su Merced el Sargento Mayor Don José Antonio Lacayo de Briones gobernador y Capitán General desta provincia de Costarrica; como también el mayordomo, prioste, y diputados y del maestro de carpintería Francisco Barquero quien por su merced fue requerido diera su parecer según Dios, sobre el estrago que el terremoto havía echo en dicha ermita, y dixo que para el descargo de su conciencia, por lo que tocaba a la techumbre estaba amenazando ruina porque las cadenas y demás piezas principales estaban fuera de su orden y lo más de la clavazón sin firmeza y que el mantenerse se podía atribuir a milagro; y por lo que mira a las paredes aunque no es su oficio, por la larga experiencia que tiene, [...] la misma pena era de sentir se derriben de cimiento respecto de estar desplomadas y descompuestas todas que al menor movimiento de la tierra caería todo, y su Merced y los susodichos hallaron estar la hermita según y de la manera que el dicho maestro lo decía, mediante lo qual lo previno el dicho Beneficiado Don Diego de Angulo Gascón para que luego que sea requerido por el mayordomo de la cofradía de Nuestra Señora de los Ángeles en procesión pública pasare la imagen a la de Nuestra Señora de la Soledad y la deje colocada en la parte y lugar que hubiere más decente, y fecha esta diligencia por los presentes concede su bendición y licencia al Capitán Blas de Ancheta como Mayordomo que de la Soledad y la Cofradía de Nuestra Señora de los Ángeles, para que pueda desbaratar y desbarate la dicha hermita y se haga cargo de tejas, maderas y clavazón, constando todo por escripto y luego se trate de la reedificación de dicha hermita y para ello dio su Merced facultad al dicho Mayordomo para que pueda gastar y [parte] de los vienes de dicha cofradia, previniéndole que no ha de intervenir alajas de oro, plata ni piedra preciosa, ni que por razón del gasto de la dicha obra se dejen de decir la misa y demás gastos precisos, y por constarle a Su Merced que dicha cofradía no tiene caudal bastante para la conclusión de dicha obra puede el dicho Mayordomo cada vez que sea menester pedir una limosna en toda la provincia y en la de Nicoya para ayuda de los gastos y esto sea dando parte al dicho Beneficiado Don Diego Angulo Gascón como [renglón muy borrado: ..... y .... dicho .... y si] por ser obra tan pia desde luego interponer su Merced dicha general visita su autoridad y judicial de cierto para que valga y haga fe: Dado en la ciudad de Cartago en el referido día mes y año mencionados y lo firmó Su Merced por ante mi el infrascrito notario de visita de que doyfee:

Manuel Jiménez de Leon Por mandato de su Merced dicho señor visitador 
Diego de Alvarez y Cabeza de Vaca, Notario Público" (Archivo Eclesiástico de la Curia Metropolitana, Fondos Antiguos, Caja 7, folio 296).

En los documentos anteriores se observa la referencia a Nicaragua, porque desde 1550 hasta 1850, Costa Rica perteneció a la silla Eclesiástica de San Jorge, que era conformada por las provincias de Nicaragua y Costa Rica, siendo la sede del obispado la ciudad de León de Nicaragua. En el tiempo del escrito, estaba como obispo de esta provincia eclesiástica Fray Benito Garret y Arloví, cura premostratense, que fue nombrado obispo de Nicaragua y Costa Rica en 1708. Entre marzo y mayo de 1711 realizó su visita apostólica a la provincia de Costa Rica y posteriormente fue separado de su obispado en 1716 debido a una disputa con la Audiencia de Guatemala (Sanabria, 1984). Asimismo, el documento alude al prioste que era el mayordomo de una cofradía.

Durante el periodo colonial se le daba mucha importancia al rescate de la mayoría de los materiales, sobre todo la clavazón (clavos) pues estos eran escasos en la provincia de Costa Rica. Se conocen documentos en donde se dejaban como herencia libras de clavos. Esto refleja una necesidad de la provincia y también su aislamiento de los centros económicos y comerciales de la América Central. Es por eso que en los documentos se insiste tanto en el rescate de los materiales de construcción, entre ellos la clavazón.

El terremoto de 1715 se ubica con más precisión en el tiempo, pues se le conoce el mes (enero) aunque no el día de ocurrencia. Parece que originó daños aislados en la ciudad de Cartago. Esto junto con la información implícita contenida en Peraldo \& Montero, (1994) sugiere que la intensidad MM pudo llegar a VI+. Este valor de intensidad máxima es porque se considera que los daños fueron aislados, pues en el documento hace referencia a la capilla de la Soledad ubicada en la ciudad de Cartago, esta capilla empieza a ser referida desde 1615. Es de suponer que esta capilla no tuvo daños severos a raíz del terremoto porque de lo contrario las imágenes del templo de los Ángeles no hubieran sido trasladadas a ese edificio. Al igual que para el sismo de 1678 , a este sismo no se le puede sugerir una fuente sísmica.

\section{Documento explícito de información sísmica sin ubicación temporal}

En el mes de septiembre de 1719, se realizaron gestiones para cobrar los cargos que sobre una casa existían producto de una capellanía. Al parecer, la casa estaba tan dañada que fue declarada inhabitable y tenía que ser demolida desde los cimientos, o bien darse en remate público. $\mathrm{La}$ anterior petición fue el 20 de mayo de 1720 . Al seguir la lectura del legajo correspondiente, se localizó una carta que relaciona los daños en esa vivienda como producto de unos temblores recientemente acaecidos. Esta carta no tiene fecha, pero se supone es de finales de 1720 ya que la fecha del último pregón de remate es del 11 de octubre de 1720 y a juzgar por el orden del legajo donde se encuentra este documento, esta carta es posterior de los pregones de remates que sobre la capellanía cayeron. Además, en el legajo la foliación es consecutiva. Esta secuencia no está bien interpretada en Peraldo \& Montero (1994). El documento de interés es el siguiente:

\section{“Señor Vicario Juez Eclesiástico}

El Licenciado Joseph de Guzmán y Echeverría, presbitero domiciliario deste obispado y Sachristán mayor de la Santa Iglesia parroquial desta vuestra Ciudad de Cartago por el Real Patronato, en devida forma y como mejor proceda parezco ante vuestra Merced y digo que sobre las cassas que fueron últimamente del Capitan Juan Lopez de la Rea y Soto en esta dicha ciudad tenía el Licenciado Don Manuel de Guzmán mi hermano residente en la de Guatemala y de quien soy apoderado general como consta del que debidamente presento ante Vuestra Merced, y pido se me devuelva seis y cientos pesos principal de que es capellán servidor por muerte del Licenciado Don Manuel de la Rea y Soto en que existía dicha capellanía: y con el motivo de haber quedado dichas casas deziertas y maltratadas a causa de los terremotos anteriormente acaecidos, me hallo con noticia cierta que se hicieron autos de utilidad el Jusgado Eclesiástico los mismos que oi paran en el de Vuestra Merced y que estos no se finalizaron 
en el to[do] por faltarles la circunstancia de prorrateo en ese dicho mi hermano y licenciado Don Juan Joseph Camacho que assimismo tenía censo sobre dichas casas adjudicándola a cada uno la cantidad que se devía tocar según su capellanía y la del remate de dichas casas que fue según me hallo notificado lo de seiscientos pesos en moneda de cacao por todo lo qual a Su Merced pido y suplico se sirva mandar traer a la vista los dichos autos y que haga el [...] que llevo pedido, y fecho que sea mandar a la persona en que ubiere entrado dicho principal hago reconocimiento en forma a favor de mi parte para que de este modo pueda percibir la renta y que no sese el sufragio según la disposición delante de dicha capellanía, en todo lo qual espero recibir su merced con justicia del Justificado Tribunal de Vuestra Merced, y juro en ánima de mi parte lo necesario. Joseph de Guzmán y Echeverría”

De este documento se hace necesario referirse a algunos aspectos de interés que vienen en el discurso documental, porque nos sitúan en el contexto político y económico del periodo. El documento empieza con una referencia al Real Patronato que consistió en un conjunto de privilegios y derechos que la bula del papa Alejandro VI pasó a la corona. Velásquez (2005) refiere que esta situación hizo de la iglesia en América una falange de la administración colonial. Queda claro, entonces, porque en materia de bienes inmuebles afectados por eventos naturales, tanto la Iglesia como la Corona se interesaran por el destino de la construcción. Un interés eclesiástico sobre los bienes inmuebles era la fundación de una capellanía sobre los bienes testados a favor de la institución eclesiástica. Los bienes destinados a la capellanía se colocaban en arriendo, los cuales devengaban un 5\% de réditos anuales, que el capellán cobraba por decir misas a favor del alma del testador, quien era el fundador de la capellanía (ver Velásquez, 2005). Debido a los aspectos económicos de fondo, el beneficiado capellán, tenía que interesarse por la capellanía, pues eran el medio de sus ingresos fijos, de aquí porque los daños generados en viviendas, parcelas, cacaotales, entre otros, tienen que ser buscados en libros de capellanías. En el caso que nos atañe, el fundador de la capellanía fue don Manuel de la Rea y Soto a favor de don Manuel de Guzmán. Entonces, cuando la base de la capellanía por algún motivo se destruía, los problemas sobre los bienes empezaban, sobre todo cuando mediaban intereses de terceros sobre los bienes, en este caso corresponde a don Joseph de Guzmán y Echeverría, como apoderado general de don Manuel de Guzmán. La propiedad fue rematada en seiscientos pesos en “... moneda de cacao...". Era común que por esa época se sirvieran del cacao como moneda circulante. Esta costumbre venía desde nuestros indígenas.

Llama la atención la referencia de varios terremotos en el documento. Se puede interpretar que podría corresponder con el sismo de 1715 , aunque los documentos transcritos para 1715, hacen referencia a un solo terremoto. Esto podría también sugerir que es una referencia para una secuencia sísmica posterior al año de 1715 y anterior a 1720. Peraldo \& Montero (1994) interpretaron que este documento está refiriendo un evento sísmico posterior al terremoto de 1715 . Esto se sustentó en función de que los documentos refieren un solo temblor para 1715 , mientras que el documento transcrito en este apartado, hace referencia a unos terremotos que ocurrieron anteriormente, que puede interpretarse como "recientemente". Además, existe un dato implícito de Thiel (1983), que refiere que en junio de 1718 se cayó una parte del lienzo o costado del templo parroquial de Cartago, que se ubica muy cercano al tiempo de la carta transcrita. Sin embargo, por los contextos de los documentos, no parece que sea la misma actividad sísmica. El periodo de 1718 a 1720 es un periodo que queda por indagar con más detalle a fin de esclarecer la incertidumbre que plantea el documento transcrito en cuanto a la fecha de la actividad sísmica reportada.

Finalmente, no deja de ser interesante las circunstancias por las cuales se reporta el evento sísmico. Se debió al interés de los capellanes por activar el mecanismo legal para recuperar, en parte, sus medios de vida. Esto explica que sean pocos los documentos que se han encontrado refiriendo daños asociados con sismos, pues no se podría pensar que solamente esa casa fue afectada, pero si es lógico pensar que solo esa casa importaba 
porque era el asiento de una fundación de la institución eclesiástica. Por otro lado, la mayoría de vecinos eran pobres y no podían darse el lujo de establecer una capellanía.

\section{Temblor del 17 de septiembre de 1727}

Los documentos relacionados con el sismo del 17 de septiembre de 1727 hacen referencia a daños en viviendas ubicadas en la ciudad de Cartago. Los siguientes documentos son parte de un proceso que se seguía para eliminar la obligatoriedad de la capellanía a los dueños o albaceas de propiedades erigidas en testamento. A veces los trámites eran engorrosos, pues como se verá, cuando convenía a los beneficiados, se cuestionaban hasta los más mínimos detalles para no perder los réditos que les devengaba la capellanía fundada en esas propiedades.

"Señor Vicario y Juez Eclesiástico

Doña Balthasara Pan y Agua, viuda y vecina vuestra de ésta ciudad, en debida forma y según derecho ante vuesía y digo = que las casas de mi morada están obligadas a diferentes capellanías, de que tengo pagados los réditos de los años que tengo asiento en ellas y ahora, a causa del temblor que se experimentó el día diez y siete del corriente, las ha deteriorado en tal extremo que no se puede habitar en ellas, por cuya razón y no ser yo obligada a reparar las causas naturales, se ha de servir vuestra merced meritos de justicia de hacerle saber a el patrón y capellán que es don Gil de Alvarado por la parte del Lic. Don Hermenegildo de Alvarado, su hermano, y el mayordomo de Cofradía de Nuestra Señora de la Concepción y vuestra merced, como cura que es uno de los capellanes, quería hablar por que pasar a hacerse la trasada, disponiendo lo que mejor le pareciere y dándome a mí por cuenta y apartada della obligación de las causas, en tiempo, conforma y conforme a dicha la obligación que hago de las dichas casas por ser los motivos justos, por lo tanto = A Vuestra Merced, pido y suplico me aya por presentado en tiempo, provea y mande según yebo predicho que es acerlo así [recibo] justicia, y juro en forma de no ser de malicia es este mi pedimento y en lo necesario.
Doña Balthasara Paniagua [firma] (Archivo Eclesiástico de la Curia Metropolitana, Caja 15, folios 444 - 446)

Es interesante referirse a dos detalles del anterior documento: 1) que el apellido Paniagua aparece separado como Pan y Agua. Igual ocurre con el apellido Oconitrillo que antes era Ocón y Trillo. 2) que esté firmado por una mujer, lo que significa que aparte de que era una mujer relacionada con las clases dominantes, también tenía condiciones culturales favorables, porque en esa época eran sumamente escasas las mujeres que sabían acaso firmar.

La respuesta se basó en la estructura legal colonial en donde había una ley que indicaba que cuando existían daños por eventos naturales, se les admitía a los afectados el beneficio de levantarles la obligación de la capellanía, como queda confirmado a continuación.

"En la ciudad de Cartago, en diez y ocho días del mes de septiembre de ese año de mil setecientos veinte y siete ante su Merced el Licenciado Don Manuel González Coronel, cura ínterin del medio beneficio de esta dicha ciudad, vicario Juez Eclesiástico en ella y su jurisdicción se presentó la dicha solicitud por lo contenido en ella con su[roto] su Merced la ubo por presentado y proveído $=$ Por presentado y en atención de ser practica corriente en este obispado de Guatemala, admitirse las oblaciones que se hacen de las casas, y más cuando las deterioridades que padecen son a causa de temblores y otros accidentes naturales, y que no son los inquilinos obligados a estos accidentes por ser irresponsables, admítesele la oblación que hace de la dicha casa y hágaselo saber a los interesados, para que dispongan lo que mejor les parecieren seguro del principal, así lo proveyó, mandó y firmó Su Merced, por ante mi el infrascrito notario de que doy fee:

Manuel José Coronel, [rúbrica] Cura Ante mí Joseph de Morales [rúbrica] Notario Público" (Caja 15, folios 444-446, Curia Metropolitana)

En el siguiente documento la jerarquía eclesiástica impone una condición a fin de asegurarse plenamente si doña Baltasara de Pan y Agua decía la verdad o estaba justificando en función del evento sísmico, el levantamiento de su obligación de la capellanía fundada. Para este fin don Manuel González Coronel solicita que dos 
personas "inteligentes" ausculten la vivienda para contar con un criterio competente.

"Ruego incontinenti en dicho día mes y año yo el infrascrito notario, suso mencionado hice saber la petición y de estas intensiones al Capitán Don Gil de Alvarado, quien prestando oído vino y otrosí dijo que se llamen dos personas desinteresadas que reconozcan la deterioridad de las casas es causada del temblor; por que esto cierto en que antes del temblor, tenía la dicha casa una rajadura y con lo que difieren las dichas personas que se nombraren, se le hará saber y responderá lo que tuviere por conveniente, esto dio por su respuesta y lo firmó por ante mí de que doy fee:

Don Jil de Alvarado y Jirón [rúbrica] Ante mi Joseph de Morales [rúbrica] Notario Público" (Caja 15, folios 444-446, Curia Metropolitana)

Se realizó el trámite nombrando a las personas “inteligentes", las que recibieron el juramento de rigor y rindieron su informe sobre el particular:

"En la Ciudad de Cartago en veinte y ocho días de septiembre deste año de mil setecientos veinte y siete, su Merced el Lic. Don Manuel González Coronel, cura interin del Medio Beneficio de dicha ciudad, vicario juez eclesiástico, en ella y su jurisdicción, con vista de lo respondido por los patrones, y capellanes de los que estan fundadas sobre las casas de doña Balthasara Paniagua, y de que tiene hecha oblación y lo que su respuesta consta digo que devía mandar y mando se haga el reconocimiento que piden y para eso nombrara y nombró al Sargento Francisco Barquero, y a Matheo Rodríguez, maestros de carpintería y los únicos que di en esta dicha ciudad que tengan inteligencia en el particular, y estando presentes los suso dichos les recibió juramento, su Merced que hicieron por Dios, Nuestro Señor y una señal de cruz en forma de derecho so cargo del qual juramento prometieron de obrar bien, y fielmente el oficio y el que aceptaron y pasaron a hacer el reconocimiento dicho con asistencia de Su Merced y por ante mi el presente notario público y aviendo visto y registrado la dicha casa por dentro y por fuera, y hecho todas las diligencias que les parecieron convenientes dijeron que están incapaces de habitarlas [...] y es el notorio riesgo en que se hayan pues además de haverse avierto por las paredes, y todas ellas rajadoce [...] se han desencajado las cadenas o coleras que atraviesan por en el medio forzando los clavos de sus ajustes con la fuerza que izo el temblor. Por estas razones son de sentir que no tienen ningún reparo las dichas casas si no es el volviéndolas a fabricar, comenzándolas por el suelo y levantando las paredes de los cimientos dellas, por que de otro modo tienen por sin duda que se caerán y entonces se experimentará que se pierda el material de arriba que por ahora se puede aprovechar; esto dijeron dichos reconocedores, y que han usado su oficio sin fraude ni dolo, so cargo de juramento que fecho tienen haciendo el reconocimiento según conciencia a su leal saber y entender y lo firmó el dicho Barquero y dicho Rodríguez no lo hizo porque dijo no saber, firmolo su Merced con el supra dicho y por ante mí el infrascrito notario de que doy fee.

Manuel González Coronel, Francisco Barquero, Ante mi Joseph de Morales Notario Público". (Caja 15, folios 444-446, Curia Metropolitana)

Peraldo \& Montero (1994) sugieren que el daño asociado con este sismo en Cartago parece fue aislado. Estiman una intensidad MM VI+ en Cartago. Es interesante que las citas refieren la ocurrencia de un solo terremoto, lo que no es muy común cuando un sismo se asocia con una falla cortical cercana. Sin embargo, dada la escasez de documentos y de datos sobre este evento, no se puede inferir nada adicional.

\section{Temblor del 26 de marzo de 1728}

Este es otro sismo cuya información de daños se ubica en la ciudad de Cartago. No obstante la cercanía temporal del terremoto de 1727 , pudo hacer que los daños ya existentes aumentaran. En un caso como este es muy difícil separar cuáles daños corresponden realmente con este temblor. El siguiente documento presenta el folio de frente sumamente borrado, pues si bien no es un palimpsesto, va a tener que ser leído mediante técnicas de rayos X. De la década de los años de 1980 al presente se han indefinido más caracteres.

"El Capitán Cayetano Muñoz, vecino desta ciudad, teniente Juez Eclesiástico [borrado] ante Usted, y parezco en devida forma [borrado] y 
digo, que a causa de un gran terremoto experimentado el día 17 del mes de setiembre del años próximo pasado, se deterioró las casas que fueron de doña Balthasara Paniagua de las que entonces hizo la suso dicha oblación ante Vuestra Merced, y a méritos de justicia se le admitió comparecer de los interesados y aviendo quedado como dichos deterioros de [borrado] del día beinte y seis de éste pasado mes de marzo otro mayor terremoto [borrado, se infiere por contexto] por las paredes se vino a los suelos parte de dicha casa perdiéndose algunos tejados, ventanas que se maltrataron y algunas piezas de madera que sirven de umbrales, que están al riesgo de perderse por estar tiradas en la caye en cuios méritos a dezersiorarse Vuestra Merced de mandar a los interesados cooperen y ayuden al desvarato de dicha caza, que yo, por la parte del Beneficiado don Fhelis Esteban de Ozes Navarro estoi [presto] a concurrir asta asegurar los materiales de dichas cazas, y caso que los dichos interesados se escuzen, estoi presto yo a azer todo lo que se pretende de mi cuenta, con el cargo de que se me halla de pagar el costto que hiciere en los mismos materiales al precio que sea baluado y asímismo, reciva en mi poder los doscientos pesos [borrado] como a mi parte de Beneficiado en el solaz. [roto y borrado] materiales por la cantidad en que fueron abaluados, que así mismo se servirá Vuestra Merced de mandar se hagan dichos abaluos y fechos, que se aseguren quando no fuere en el todo en la parte que alcanzaren las capellanías que se hallan sobre dichas cazas porque no se pierdan en el todo por todo lo qual = A Vuestra Merced pido y suplico mi halla por presentado en nombre de dicho mi parte el Beneficiado Don Fhelis de Ozes, en [tiempo: no hay seguridad en la transcripción de esta palabra] y forma provea y mande según yevo pedido por ser de justicia, y en seguro de los vienes que se hallan convertidos en sperituales y que están en riesgo de perderse del todo juro en forma y en lo necesario.= entre renglones $=$ asi $=$ Vuestra Excelencia, Cayetano Muñoz Bermúdez." (Caja 13, folio 267, Curia Metropolitana)

Para esta fecha queda la incertidumbre si Baltasara Pan y Agua había muerto, pues se refieren a ella en pretérito. No obstante, aquí termina la información sobre el trámite que se le siguió a las casas de Balthasara Pan y Agua, sin que se sepa en qué desembocó la causa. Sin embargo, queda claro que las casas no fueron derribadas luego del sismo de 1727, como se había determinado debía de hacerse.

Peraldo \& Montero (1994) estiman una intensidad VI+ en Cartago y además sugieren que los temblores de 1727 y 1728 podrían corresponder con rupturas de dos zonas sísmicas del margen convergente del Pacífico de Costa Rica, esto con base en la generación de un único temblor para ambos casos y los daños aparentemente aislados en la ciudad de Cartago.

\section{Temblor de 1746 en Matina}

El siguiente es un documento que se conserva en el Archivo de la Curia Metropolitana de San José, fue transcrito por el historiador y escritor Manuel de Jesús Jiménez. Es un documento de una riqueza descriptiva importante para estudios geográficos históricos, sismológicos y meteorológicos. Pertenece a un legajo de cerca de 40 folios que corresponden con los autos para la reedificación de la capilla y del fuerte de San Fernando de Matina. Estos autos tienen una riqueza descriptiva impresionante, sin embargo, por causas obvias se transcribe la parte que refiere el terremoto de ese año.

"Señor Gobernador y Capitán General = Señor = El Alférez de este fuerte de San Fernando de la boca del río del valle de Matina, Don Luis Arnesto de Troya, comandante interino de dicho fuerte, haze saber a Vuestra Señoría como el día diez y ocho del mes de junio de este presente año de quarenta y seis por la noche ubo tal corriente de este río que inundó este fuerte por fuera y dentro que quedaron las casas totalmente desquiciadas y sin haber paraje en todo el dicho fuerte en donde poder estar de pie; y luego el día veinte y uno de dicho mes como a las onze del día sobrevino del mar un huracán que nos puso en grande horror y confusión pareciendose ser los últimos días de la vida, llevandose de encuentro en su primera furia la casa en donde viven los oficiales quedando en el todo destruido é inservible, como también la casa quartel de las armas quedó tan sin quisio ni seguro que por instantes se teme su total ruina como con todo lo demás que tengo 
informado previniendose antes de estas ruinas un temblor que duró por el despacio de una ora con lo que hemos experimentado la furia y bigor de los elementos por lo que estamos sumamente aterrorizados y por faltarnos los víveres en el todo pues ni luz ni carne ni agua que beber porque la que el río vaja siendo por su naturaleza mala con sus contínuas crecientes está hecha lodo por lo que se hace inábil para mantener la vida humana. A el padre capellán lo puse a salvo retirándolo á la hacienda del Sargento Mayor Don Dionisio Salmón Pacheco por ser la parte más cómoda y próximo para la administración de este fuerte, yo con mi continuo padecer, mantengo en esta indecencia assí por el cumplimiento de mi obligación como por aguardar la última determinación de Vuestra Señoría así de esto como de los demás consultas que sobre los acontecimientos de este fuerte tengo echos. Fuerte de San Fernando de Matina, y junio veinte y dos de mil setecientos quarenta y seis años = Señor Gobernador y Capitán General = Besa la mano de su Señoría su más rendido súbdito = Luis Arnesto de Troya." (Archivo Eclesiástico de la Curia Metropolitana, Caja 1, folios 496 a 520).

Con respecto al temblor, destaca que se sintió sumamente largo aunque no se reporta que el mismo provocara algún daño especial. Peraldo \& Montero (1994) analizaron la información conocida para este sismo y estimaron una intensidad entre VI y VI+ en Matina. Sin embargo, estos autores consideraron que la información es sumamente escueta para definir otros parámetros macrosísmicos. Resalta la descripción sobre la inundación, así como el daño que provocó el huracán, que derribó la portada de la ermita del fuerte.

\section{Terremoto del 4 de marzo de 1756}

Estos temblores provocaron daños al parecer de importancia en viviendas de la ciudad de Cartago. Nuevamente los daños se reportan en viviendas donde hay capellanías fundadas.

Sr Vicario Provincial y Juez Eclesiástico

Don Joseph Hermenegildo de Arleguí, clérigo Presbítero y domiciliario de este obispado, ante Vuestra Merced parezco y digo que en la plaza de esta ciudad, esta una casa grabada con setecientos pesos de plata pricipal[sic] de dos capellanías, la una de quinientos pesos pertenecientes [o lo que me parece: entre paréntesis redondo en el original] a el alma de fulano[sic] Macotela, la qual se alla actualmente sin capellán por haber fallecido el último que lo fue el Presbitero Don Juan José Solís, y la otra de doscientos, pertenecientes al alma de Doña Eugenia de Abarca, mi bisabuela: de la qual soi capellán en propiedad, y por el motibo[sic] de que ha tiempo de veinte años que no redituan dichas capellanías por falta de inquilino, y hasta ahora he estado yo diciendo las misas, sin estipendio alguno, y con la pensión de veinte pesos que he pagado anualmente a la fábrica de esta Santa Iglesia Parrochial, además de barios gastos, que he tenido en reparar dicha casa, para que de el todo no se acabase de arruinar.

Suplico a Vuestra Merced se sirba mandar, se tase la referida casa, a presio[sic] de cacao, por ser la moneda más usual, y corriente en esta provincia por producirla ella misma; y se saque al público pregón, rematándola en el mayor postor que hubiere, aunque no llegue el caso de dar toda la cantidad en que se abaluase, por que peor será, que suceda el que se benga abajo, como ha sucedido con otras, y se pierda todo: pues sin en bargo[sic] de los reparos que hice en la ruina, que padeció, con los grandes temblores, que hubo por el mes de jullio de este presente año, está sumamente deteriorada que es naturalmente imposible dege de caerse el ynvierno[sic] benidero, sí no ai quien la compre, y le haga un formal reparo de el manifiesto deteríoro que padece: en cuya atención = A Vuestra Merced suplico me aya por presentado, provea, y mande lo que tubiere[sic] por conveniente, por redundar en bien de las ánimas del Purgatorio; y mirando no sea de mi cargo, como me ha acontesido, por otra, juro no proceder de malicia éste mi pedimento, y en lo necesario. Joseph Hermenegildo de Arleguí.

Otrosí digo, que para comprobación del gran deterioro que padece dicha casa, pongo presente a Vuestra Merced que en los temblores, que llevo dicho entre las ruinas que padeció la mencionada casa se cayó enteramente la cosina [sic], como está de manifiesto, la qual estaba contiguo a la casa, y fundamentada como ella misma de que se sigue por clara consecuencia, que sucederá lo 
mismo con dicha casa; sin embargo de los reparos que he hecho pido: su Vuestra Supra = Joseph Hermenegildo de Arleguí. (Curia Metropolitana, Caja 24, fs. $54-56$ )

Este documento es dirigido al juez eclesiástico, quien tiene todo el poder para tomar la decisión sobre la solicitud referida, pues era esta la figura a quien se le encargaba de dirimir afrentas morales y velar por las obras pías (Cf. Velásquez, 2005). Aquí de nuevo, un beneficiario de una capellanía, solicita al juez eclesiástico que vea de que manera puede dar en pregón la propiedad para rematarla en precio de cacao. Asegura que la cocina se cayó debido a los temblores y que a la casa le corresponderá igual suerte. Es de recordar que por aquel tiempo, algo que incluso todavía hoy día se observa en algunas viviendas de zonas rurales, la cocina solía estar separada del cuerpo principal de la construcción, posiblemente para evitar incendios.

Peraldo \& Montero (1994) comentan que los daños documentados para este terremoto están ubicados en la ciudad de Cartago. Además se conoce información implícita sobre daños en fecha posterior y temporalmente cercana a los eventos de 1756 para otras poblaciones cercanas a la ciudad de Cartago. Le asignan una intensidad en el ámbito de VII - VIII en la ciudad de Cartago.

\section{Terremoto de Barva del 15 de febrero de 1772}

Este temblor es el primero conocido que provoca daños en una ciudad diferente a la ciudad de Cartago como es la población de Barva. En esta población se afectó el convento de San Francisco y parte de la iglesia respectiva.

"Señor Vicario provincial Juez Eclesiástico

Fray José de Villanueva de la orden de los frayles menores de la regular observancia de nuestro Seráfico Padre San Francisco predicador exdefinidor, y cura doctrinero [roto] éste pueblo de San Bartolomé de Barba, parezco a[roto: $n$ se infiere por contexto]te Vuestra merced en la mejor vía, y forma que en dicho lugar haya, y digo que habiéndose experimentado en éste valle el [roto]rromoto que hubo el día quince de febrero próximo pasado, con el que se causó el estrago, y desgracia de [és] te convento de dicho pueblo con la ruina de haber caído de un todo, y dicha iglesia quedado en pie [por permisión del Altísimo: entre paréntesis en el documento], pero ha quedado con tal delicadesa por el desquiciado, y desplomado que se ha reconocido, estar tan bencida e hida la parte del norte, cuyo [da]ño ha sido registrado por muchos vecinos, y maestros que [di]cen necesita de apearse, para su mejor seguranza, para cuya execucion necesito de la venia de vuestra merced, y juntamente la conmiseración de los naturales e hijos de éste dicho pueblo, por ser tan infelices, que no tienen más que su trabajo personal, y siendo preciso costiar maestro de afuera por no haberlo en los indios como lo pide la hobra[sic] y, así mismo, costiar algunos materiales de fierro, y teja y lo más que se puedan ofrecer, para cuyo auxilio suplico a Vuestra Merced haga que las cofradías que tiene ésta Santa Yglesia cuallugen[sic] a si en lo dicho como en lo demás a la mantención de carne para el trabajo de dicha iglesia, de cuyas todas providencias espero del gran celo de vuestra merced la expresa horden para la execución, por todo $=$ A Vuestra Merced pido, y suplico me haya por presentado en éste asumpto en tiempo, lugar y forma, provea y mande lo que convenga a favor de ésta pobre iglesia de lo que yo receviré bien y merced. José de Villa Nueva [Frayle]. "(Curia Metropolitana, Caja No. 27, Folio 399)

Como ejemplo de las dificultades paleográficas, nos referimos a la tercera línea del anterior documento. Se transcribió lo siguiente a[roto: $\mathrm{n}$ se infiere por contexto]te. En este caso Ante, como debe leerse, quedó al final del renglón que conserva la a pero la $\mathrm{n}$ ha sido destruida pues el borde del documento está roto, y en la siguiente línea viene la sílaba te y así hay varias líneas que son inferidas por contexto porque sus bordes incluyen hasta una palabra desaparecida.

A vuelta de folio 399 viene la siguiente respuesta:

Cartago Marzo 13 de 1772

Por presentado; líbrese despacho, para que los mayordomos de las cofradías del pueblo de San Bartalomé de Barba ayuden a la reedificación de la iglesia de dicho pueblo; dando cada mayordomo de la cofradía que es a su cargo, lo que para ayuda del trabajo de dicha iglesia fuera necesario. Lo cual proveyó, mandó y firmó 
su merced, el Beneficiario Don José Francisco Alvarado y Jirón cura según el Real Patronato de la Santa Iglesia Parroquial de esta ciudad de Cartago, y sus anexos, y Vicario Provincial y Juez. Eclesiástico en esta Provincia de Costa Rica, doy fe Fernando Antonio de Arleguí, Notario Público

En las cuentas de fábrica del año 1773 realizadas por don Manuel del Corral, en la Cofradía del Santísimo de Heredia se lee en el descargo del mes de diciembre de 1773:

"Idem 4.0 ps gastados en junio para clavos con qe se aseguró el retablo mayor qe se havía falseado con los temblores." (Libro de Cuentas de Fábrica y Cofradía del Santísimo de Heredia, vol. 6)

No se sabe si los temblores que son referidos en el anterior documento corresponden con el terremoto de Barva y sus sismos réplica, o bien, son otros temblores ocurridos en 1773. No se han localizado fuentes documentales primarias que aclaren esta incertidumbre.

Desafortunadamente, no existían muchas poblaciones alrededor de Barva, salvo la villa de Cubujuquí, posteriormente denominada Heredia. Peraldo y Montero (1994) sugieren que el sismo podría estar relacionado con una fuente cortical ubicada al norte del Valle Central, en el sistema de fallas de Alajuela, y le asignan intensidad de VII a VII+ en la población de Barva y de VI a VI+ en Heredia.

\section{Temblores de 1794}

Estos temblores afectaron una estructura en la ciudad de Cartago y además, es la primera referencia conocida sobre daños en la ciudad de San José.

"En el mes de julio de mill setecientos noventa y quatro años ..., con anuencia del Sr Cura y Vicario Dn Ramón de Azofeifa ... comparezcan dos albañiles, dos carpinteros y otros quatro ... y hagan escrutinio a la Parroquial de esa Ciudad, reconociendo las lecciones que el templo tenga, además de los que tenía, o si han tomado aumento con los temblores en la [ ] presente .... comparecer ante si a Rafael Pacheco, Maestro albañil y vecino desta ciudad ... y dixo: que las paredes del cañón principal de la iglecia como se hestaban se están, sin novedad alguna en afección y que las paredes de la capilla de las Animas, que se hallan partidas en todas quatro esquinas y que es regular que como [ ] que están hasta abajo pueden desmoronarse y benirse abajo, por cuia razón le parece el que no se pueda selebrar en ella ... comparecer ante sí al Maestro en Carpintería y Albañilería Antonio Saenz ... y dixo: que según el exploreo que ha hecho según su oficio y práctica que tiene, no advierte que la fabrica de la iglesia tenga mayor lección que lo que antes tenia ... y que sin riesgo ninguno se puede celebrar los divinos oficios ... comparecer al maestro Juan [Murga] carpintero ... y dixo: que haviendola reconocido no le encuentra pr aora según el estado en que está peligro alguno y que se puede a su parecer selebrar sin riesgo alguno los divinos oficios ... comparecer ante si a Don Andrés Volandi ... y dixo: que según el exploreo que ha hecho le parece no tener ni en sus paredes ni en su techumbre mayor lección que impida celebrar los divinos oficios, pues la lección que se manifiestan le parece son las mismas que ha conocido ..." (Archivo Nacional, Sección Histórica, Serie Cartago, No 0919)

El anterior documento presenta un criterio práctico que se oponía a continuar celebrando misa en el templo, contra tres criterios que apoyaron la tesis de que la fábrica del templo no había presentado daños que no fueran los que ya tenía. $\mathrm{Al}$ respecto, consideramos prudente asumir para el análisis los criterios similares, por tal motivo se considera que el templo no llegó a tener daños de importancia debido al sismo ocurrido, incluyendo el cañón que es el cuerpo principal del templo.

En San José se reportó daños en la factoría de tabacos. Este edificio se encontraba ubicado donde actualmente se localiza el Banco Central, en la esquina SE del cuadrante, limitaba la Factoría con el Palacio Nacional y hacia el oeste con el templo de la Merced.

"El domingo 4 del corriente como a las 8 de la mañana, se experimentó en esta, un fuerte terremoto, de manera que en esta casa factorial y Almacenes de ella ha causado algún daño, de que no damos razón individual, a causa que están continuando dichos temblores por lo que si la divina majestad no nos mira con ojos de piedad y cesan en el venidero se remitirá la diligencia formal del deterioro y costos que puede originarse 
pues hasta la fecha es algo considerable el daño, y por pronta providencia se mandaron recorrer los tejados de almacenes y casa y comprar cien tejas que faltaban y se quebraron para evitar goteras. Los cuatro intermedios desde el cuarto dormitorio hasta la cocina se ha lastimado bastante, que puede que sea necesario echarla al suelo. La pared que está confinada con el estanque tiene dos endeduras: El almacén que esta al salir de la cocina, a la izquierda, se ha abierto más la endedura conque desde su principio quedó. El cuarto que cae a la calle, el intermedio que divide al inmediato a la puerta del zaguán, y de la oficina, se ha hecho apear y unirlo de manera que ha quedado capaz para dormitorio y vivienda del factor. Dios guarde a vuestra merced, Villa Nueva y mayo 9 de 1794.

Abalúo que formamos don Cornelio Fernández, Manuel Golfín, Antonio Muñoz inteligentes de las obras de cantería y albañilería del costo que a el poco más o menos puede tener hacer de cal y piedra el intermedio de esta factoría, que media entre el cuarto dormitorio del señor factor y la pieza que sirve de espensa, que se debe construir de nuevo por estar todo rajado, y desplomado a causa de los temblores que ha abido, cuyo costo regulamos en la forma siguiente:

Primeramente para apiarla y sacar la tierra consideramos la pueden hacer en un día ocho peones que a dos reales cada uno importa dos pesos --- $2 p$.

Para el simiento y paredes se consideran como diez y seis o veinte carretadas de piedra de cantería que a razón de dos y medio reales cada una hacen --- 6 p.

Para la construcción de dicha pared se consideran como quatro fanegas de cal que a razón de nuebe fanegas hacen --- $15 \mathrm{p}$.

E igualmente se consideran veinte y ocho fanegas de arena que a real la fanega hacen --- 3 p. 4 r.

Se necesita para hacer esta fábrica siete días de un maestro albañil que a razón de sinco reales de formal importa --- 4 p. $3 \mathrm{r}$.

Y cuatro peones en los mismos siete días que a razón de dos reales de jornal hacen --- $7 p$.

En total 38 p $7 \mathrm{r}$.

Concluimos este abalúo que hemos formado fiel y legalmente según nuestro saber y entender y por ser verdad lo juramos a Dios Nuestro Señor y una señal de Santa Cruz y lo firmamos el que sabe y por lo que no lo hace a ruego don Juan Ramírez, en Villa Nueva seis de agosto de 1794." (En el desglose del abalúo p es pesos y r es reales. Archivo General de Centro América, A3.13 Expediente No 560, Legajo No 40).

$\mathrm{El}$ anterior documento sugiere que la actividad de temblores tardó un cierto tiempo. Es interesante el abalúo que se efectúa con motivo de las reparaciones de las estructuras afectadas por los temblores de 1794. Peraldo y Montero (1999) sugieren intensidad en Cartago y en San José al menos de VI y que posiblemente pudo llegar a VII.

\section{Terremoto del 10 de abril de 1821}

Este temblor es quizás el más documentado del periodo colonial, siendo además el último de ese periodo. Este temblor ocurrió en un momento convulso de nuestra historia, por cuanto coincide con el proceso de independencia y ocurrió cuando los ánimos estaban caldeados básicamente por la discusión del futuro de nuestra patria. Existían dos bandos de pensamiento político: los liberales presididos por Gregorio José Ramírez, promulgaban sus ideas de emancipación de España y los monárquicos, presididos por las familias de alcurnia de Cartago y la oficialidad de la Iglesia, entre ellos Joaquín de Oreamuno y Muñoz, que con su temor al cambio querían seguir con el vasallaje a España.

Los documentos encontrados muestran la necesidad que se presentó de evaluar y reparar los daños que sufrieron los templos parroquiales de las ciudades de Cartago y de San José.

Documentos relacionados con la iglesia parroquial de Cartago

En el primer documento encontrado se solicita un reconocimiento por parte de "expertos" de los daños ocurridos en la iglesia parroquial:

"Martes 24 de abril de 1821

Cabildo extraordinario para el reconocimiento de la pared de esta Parroquia resultado del temblor de tierra el 10 del corriente entre $3 y$ 4 de la tarde

Los S.S. Capitulares que se suscriben acordaron:

Que para más solemnizar este acuerdo, se le pase recado político por medio de uno de los síndicos al Señor Jefe Político para que sirviéndose 
prestar su asistencia, se celebre otro acuerdo en el que estando se determinó lo siguiente: que para el día dos del inmediato mayo, en que se ha de hacer reconocimiento de la Iglesia, para la providencia, que se deba tomar para resolver una ruina, se oficie al Señor Vicario Don Pedro Alvarado, y al Señor Cura Don Juan de los Santos Madríz para que presten su personal asistencia; y que para otro día se cite al Maestro Albañil Golfín de Alajuela, y de esta Ciudad a Juan Ibarra y Dolores Ortega, y Maestros Carpinteros a Mariano Matamoros, y Joaquín Quirós; y con lo que resulte de este reconocimiento se tomará la providencia que corresponda, previo el juramento de otros Maestros y asistencia de otro Ayuntamiento.

Con lo cual se concluyó este acto que firmaron los Señores de este Ayuntamiento por ante mí el presente secretario de ello doy fe.

Juan Manuel de Cañas [rubricado]

Salvador Oreamuno [rubricado]

José Antonio Echandi [rubricado]

Narciso Esquivel [rubricado]

José María de Peralta [rubricado]

Joaquín Oreamuno [rubricado]

Nicolás Carazo [rubricado]

Félix Oreamuno [rubricado]

José Francisco Bonilla [rubricado]

Manuel José Bonilla [rubricado]

Joaquín Carazo (rubricado)(secretario)" (Archivo Nacional de Costa Rica, Cartago Municipal, número 841, Folios: 22v - 23v)

Es interesante que a finales de la colonia, ya al Cabildo se le denominó Ayuntamiento. ¿Demuestra esto acaso, un deseo de gran parte de las personas de ese periodo de eliminar la ingerencia peninsular en los destinos de las colonias americanas?

El 2 de mayo la comisión de peritos realizó la evaluación y el 14 de mayo presentó el reporte de daños ante las autoridades políticas:

"En la Ciudad de Cartago, a los dos días del mes de mayo de mil ochocientos veinte y un años, el Noble y Leal Ayuntamiento Constitucional de esta dicha Ciudad, en cumplimiento de sus deberes, y en virtud de lo acordado en acta de veinte $y$ cuatro del próximo pasado abril para el reconocimiento de la Iglesia Parroquial que deterioró el gran temblor de tierra que hubo el día diez del mismo abril, estando para su efecto reunidos en esta
Sala Capitular el Señor Gobernador Jefe Político, el Señor Vicario Juez Eclesiástico, el Señor Cura interino y los Maestros José de Jesús Golfín de la Villa de Alajuela, Mariano Matamoros, Joaquín Quirós y Dolores Ortega de esta vecindad, previa la solemnidad del juramento que hicieron conforme de Derecho por lo que ofrecieron desempeñar fiel y legalmente según su saber y entender dicho reconocimiento, y los demás individuos que componen esta corporación nos constituimos a la enunciada Iglesia Parroquial, la que vista y reconocida que fue expusieron dichos maestros: que habiendo registrado con toda exactitud la Iglesia, encontraron que el cuerpo de dicha Iglesia que es de adobe aunque no ha perdido el plomo está sumamente dañada por tener distintas reventaduras, tanto a lo largo como al traverso, y que es por consiguiente que como en este lugar hay frecuentemente temblores puede caerse dicha Iglesia; por lo que son de parecer se fabriquen de nuevo dichas paredes, pues aunque la capilla en una de sus esquinas tiene algunas raspaduras se puede remediar con unos bastiones del lado de afuera de alto a bajo; en cuya consideración procurando evitar la ruina que ocasionaría su caída, que sería casi evidente en otro temblor aún menor del día diez de abril, se ha resuelto de común acuerdo se emplumen los dos costados de las paredes de adobes, para que les ayuden a sostener el techo interior se trata de la reedificación de dichas paredes, si deben ser del mismo adobe o si cambiarlo, debiéndose dirigir con oficio por medio de los Señores Jefes Políticos este expediente a la Excelentísima Diputación Provincial para que su Excelencia en vista de él, de lo urgente de esta necesidad, y de que el fondo de fábrica se haya exhausto de numerario para obra tan considerable, se digne resolver si se debe o no compeler al público para ello; cuya diligencia firmaron los mencionados Señores Don Juan Manuel de Cañas Gobernador Político y Militar, D. Pedro José Alvarado Vicario Juez Eclesiástico, el Doctor Don Juan de los Santos Madriz, y los Maestros que supieren con los individuos que componen esta corporación por ante mí el presente Secretario $=$ testado $=$ que es que adobe $=$ no vale = Juan Manuel de Cañas = Pedro José Alvarado = Juan de los Santos Madriz = Nicolás Carazo $=$ Joaquín Oreamuno $=$ José María de Peralta $=$ Félix Oreamuno $=$ Juan José de Bonilla 
= José Francisco Bonilla = Mariano Matamoros = Joaquín Quirós = Joaquín Carazo Secretario de Cabildo (Archivo Nacional, Expediente Municipal 841: Cartago, 1821, Folios 65f-66f).

En el documento se hace referencia a la Diputación Provincial que consistió en una figura política ideada durante el tiempo que rigió la Constitución de Cádiz, cuyo centro de reuniones se encontraba en Nicaragua. En un inicio tenía representantes de Comayagua, Nicaragua y Costa Rica.

\section{Daños en la iglesia parroquial de San José}

En el Archivo Nacional, en la serie de Gobernación, número 9321, se localizaron los siguientes documentos que son de interés, pues en ellos se observa el proceso seguido para la reparación en el templo de San José.

"Acabo de saber que en Usted residen facultades, para abrir cavildo extraordinario en cualquiera día de la semana, y de Junta, exigiéndole el bien público, y sabiendo de tanta consideración el atender el perjuicio que ha padecido la iglesia parroquial por el terremoto del día diez, me ha parecido no esperar al día lunes en que pensaba [asondar] con el Noble Ayuntamiento en derechura sobre el particular, y acaecimiento referido: por tanto expreso el celo justificación se sirva informarlo así a todo el cuerpo el día de mañana, si lo tuviere a bien, el objeto de que proveamos de su pronto remedio. Dios guíe a su Merced San José, abril 14 de 1821. [Firma] José M. Esquivel.( Folio 1)

En la siguiente carta viene la respuesta a la nota anterior por parte del alcalde primero Constitucional, don Rafael de Gallegos y Alvarado, quien posteriormente fue el segundo Jefe Político del Estado de Costa Rica.

"Don Rafael de Gallegos Alcalde Primero Constitucional de esta ciudad de San José.

Por cuanto el día catorce del corriente a las nueve de la noche reciví del Padre Cura de esta ciudad el oficio que esta por caveza de este expediente rubricado por mi, el que mandé se leyese el día de hoy en cavildo abierto e impuesto el noble Ayuntamiento de su contenido dispuso en acta de este día que se reconociese el daño que ha recivido la Iglesia Parroquial de esta ciudad ocasionado por el terremoto del día diez, y para ello tuvo a bien nombrar a los peritos Rafael Chávez, Manuel Golfín, José Morales y que estos mismos tanteasen el costo que tendría demoler o reedificar el edificio según el mas o menos daño que haya recibido, y que al efecto se siguiese por mi expediente por separado sobre la materia y que concluido bolviese a aquella Corporación, y deseando cooperar por mi parte a esta obra que es del interés del bien público, y con cuyo reconocimiento se evitarán las desgracias que sucederán si se llegase a experimentar la total ruina del edificio en cumplimiento de los deberes de mi obligación y por que se cumpla lo acordado por el noble Ayuntamiento devía demandar y mando que en la misma fecha se libre mandamiento de comparecencia a los citados tres peritos para que el día de hoy sin falta alguna hagan el citado reconocimiento en los términos referidos, y por esto que proveo lo mando y firmo yo dicho Alcalde Primero Constitucional a diez y seis días del mes de abril de mil ochocientos veinte y uno. [Firman] Rafael de Gallegos, Lorenzo Díaz, Toribio".

A continuación se celebra la inspección del edificio, previa parafernalia de juramentos a los peritos de la época.

"Seguidamente yo dicho Alcalde Constitucional; estando presente el maestro Rafael Chávez, José Morales y Manuel Golfín, los notifiqué é hize saber el auto anterior y entendido del nombramiento que se ha hecho en ellos el Noble Ayuntamiento de esta ciudad para que reconozcan el daño que se ha recivido en la iglesia parroquial de esta ciudad dijeron: que lo aceptaban y aceptaron; en cuya virtud por ante los testigos de mi asistencia con quienes actúo por falta de escribano, les recibí juramento que lo hicieron por Dios Nuestro Señor y una señal de su Santa Cruz en forma de derecha, por lo cual ofrecieron cumplir el encargo con la fidelidad devida y firmó conmigo el que supo y por los dos que no saben lo hago yo con los testigos de mi asistencia de que certifico.

[Firman] Rafael de Gallegos, Rafael Chávez, Lorenzo Díaz, Toribio"

En el siguiente documento se describen los daños ocurridos en el templo.

"Yo dicho Alcalde Constitucional, en cumplimiento de lo que tengo mandado en el auto anterior, acompañado de los peritos y de los testigos 
de mi asistencia, pasé a la Iglesia Parroquial de esta ciudad, y habiéndola reconocido y examinado detenidamente expusieron los peritos: que la rajadura que tiene la portada al lado del sur se le hizo desde que la estaban trabajando, que lo hará como diez años, y que con los temblores que havido desde aquella fecha a esta presente se ha ido aumentando, en términos que puede experimentarse su total ruina sino se apea el rimate, formando [debería decir formado] este del último cuerpo en donde está la cruz, con cuya diligencia les parece quedará segura porque rebajándosele esta parte de altura se le quitará mucha simbra y por que ha llegado a perder lo más leve de sus planos: que no se hallan capaces de formar un cálculo aproximado del costo que tendría la operación, que dejan dicho en lo que se ratificaran sin embargo, de las instancias que las hize, porque sobre un poco mas o menos dijeron el costo que podría tener: y pasando adelante encontramos roto el entablado de la iglesia y dos alfagias así a la parte de la portada, cuya abería la ocasionó dichas almenas que calleron de la portada sobre el techo de la iglesia, cuyo daño está remediado con el valor de tres pesos de plata; y siguiendo mas adelante se examinó todo el cuerpo de la iglesia, y también la capilla mayor, y no se encontró daño ninguno, solo en el arco toral cuya demolición es indispensable porque amenaza próxima ruina, por estar las pilastras sobre que descansa hechas pedazos por todas partes desunidas las piedras, y aun rajadas algunas de ellas y con el desplomo de dos, [una] puerta desplomada en la altura de tres varas [por] lo que aun sin que haiga otro temblor puede derrumbarse y arruinar todo el templo y preguntándose a los peritos con que costo se podría demoler el arco, y hacerlo de madera: dijo el Maestro Rafael Chávez, que el mismo daño había padecido el arco toral de la parroquia de la ciudad de Cartago, y que se abía visto el señor vicario y aquellos vecinos á desvaratarlo construyendo de madera por la mayor baratura, mayor estabilidad y en ningún riesgo en caso de terremoto y que con don Manuel Torres que fue el ecónomo nombrado para correr con aquel trabajo graduó que se habían gastado en toda la operación cuatrocientos pesos, y que siendo igual el de esta parroquia tendría el mismo costo sobre un poco más o menos: con lo qual se concluyó este auto que firmó conmigo el maestro Rafael Chavez, y los testigos de mi asistencia no firmando los otros dos peritos por que no sabían, lo que certifico. [Firman] Rafael Gallegos, Rafael Chavez, Lorenzo Díaz, Toribio" (Archivo Nacional, Gobernación, número 9321 , folios 3 a $5 f$ )

En el folio 5v se vuelve a examinar la iglesia determinándose lo siguiente:

"En la ciudad de San José a los veinte días del mes de mayo de mil ochocientos veinte y uno, haviendose reunido los vecinos principales de la ciudad y sus barrios; en los portales y galería de la casa capitular en virtud de la convocatoria acordada por el Ayuntamiento en acta celebrada el catorce de este mes para que asiendose un nuevo reconocimiento con inteligentes del estado del cuerpo principal de la iglesia con asistencia del vecindario, deliberase este a vista de los daños u aberías que ha padecido, si puede subsistir en el mismo estado, o ha de repararse acordando el modo y forma de practicarlo, impuesto de todo se dirigieron con migo el Regidor don Ramón Saborío Alcalde Primero por depósito de vara, y demás individuos del cuerpo que [ ] a dicha parroquia a rectificar el reconocimiento prevenido con los inteligentes Rafael Chavez, Manuel Golfin y José Morales, y haviendo certificado en toda la extensión del cuerpo del centro de la iglesia desde luego se [resistió] y reconoció que amas de los daños y haverías que se havían manifestado en el cuerpo del arco toral y la portada, se halla también dañada en estado ruinoso dicho cuerpo en el sentro con considerase a que no solo se le encuentra muchas quebraduras ya perpendiculares ya trasbersales[sic], si también nulidad de su construcción por no haverse colocado la piedra de plano sino parada y tener una ilada[sic] entera a la altura de dos varas construida de piedra y barro de una forma tan deleznable que sin otro [ursilio] que de los dedos se escarva y desmorona: en cuya vista y havido consideración al estado de [ ] en que se halla el edificio con peligro de una ruina que entre otros perjuicios trahería la pérdida de los útiles de madera y teja fue de común rutina que haviendose el reparo que esta acordado anteriormente en el cuerpo de la portada el resto del edificio se reedifique integralmente y que esto se haga vajo el plan de dar a la iglesia en su latitud la extensión de dos naves más que alcanzan a cubrir las torres por que amas de ser 
esta medida de necesidad y comodidad para todos los vecinos que por la numerosa población del lugar experimentaba ya en los días festivos y funciones mucha estrechez y angustia, con detrimento de la salud publica, considerando esta ventaja, serán de poca cantidad el mayor gasto que por ello se deriva con las obras."

Este es el sismo mejor documentado de la época colonial. Esto se debe que en el año de su ocurrencia, ya existía un sistema burocrático en la administración pública más eficiente y los acontecimientos quedaban, en su mayoría, mejor documentados por los procesos y protocolos administrativos. Peraldo \& Montero (1994) sugieren que en Cartago y San José la intensidad para el terremoto del 10 de abril de 1821 fue VI+.

\section{DISCUSIÓN}

El periodo colonial de Costa Rica, se caracterizó por el particular desinterés que la mayor parte de sus gobernadores mostró por el eficaz desarrollo de la provincia más alejada y pobre de la Capitanía General de Guatemala. Esto se refleja en la información documental que se preserva en los archivos de nuestro país, sobre diversos aspectos del quehacer cotidiano y de los acontecimientos importantes que marcaron el devenir de nuestro pueblo. Antes del siglo XVIII, la documentación es prácticamente inexistente, lo cual se debe en parte porque los designados para almacenar, cuidar y actualizar los libros municipales no sabían leer o escribir, pues los puestos simplemente se compraban. Esto, junto con la destrucción física por efecto de la intemperie y los hongos, provocó que escasos documentos relacionados con temblores y otros eventos naturales llegaran hasta nuestros días. Aparte de todo esto, muchos archivos que debieron contener información valiosa, se perdieron por efecto de incendios, como fueron los de Nicoya en 1644 (González, 1910), 1683 y 1772 (este incendio se documentó en el archivo de León, Nicaragua, mediante un documento sobre el templo de Nicoya que no puede ser referido porque no está organizado en legajo, número etc), el de Boruca de 1800 (Barrantes, 2004), o el de Buenos Aires donde se quemaron los archivos de Boruca y Térraba durante la guerra civil de 1948
(Barrantes, 2004). Otro aspecto que no permitió contar con un mayor legado de información fue porque en nuestro país, a diferencia de las demás provincias, no existían verdaderas ciudades, con excepción de los últimos años del periodo colonial. La ciudad más importante fue Cartago, que tampoco contó con edificios significativos que pudieran generar una gran preocupación en el gobierno colonial para su reconstrucción en caso de algún evento natural, como si ocurrió en Guatemala o en Nicaragua. Todo esto se debe a que los españoles dieron mayor importancia a la conquista de Nicaragua (Solórzano, 2000a). Esto permitió que Nicaragua llegara más tempranamente a la colonia que Costa Rica donde incluso, la villa que fundara Hernando de Córdoba en Costa Rica denominada Villa Bruselas, fue desmantelada rápidamente por los españoles y según Solórzano (2000a) fue con el fin de tener una excusa para declarar la "justa guerra" a los aborígenes de las comarcas circunvecinas al extinto asentamiento de Bruselas.

La tardía colonización de Costa Rica permitió una escasa población y provocó que grandes áreas de nuestro actual país quedaran vacías de información sísmica, a diferencia de lo observado en otras provincias de la Capitanía General, en donde la cantidad de documentos en los archivos sobre eventos sísmicos y sus daños asociados en diversas poblaciones, atestigua una mayor cantidad de asentamientos humanos consolidados y mejor estructurados que los nuestros sobre todo de inicios del periodo colonial, un periodo oscuro, si se quiere, de nuestra historia patria. A inicios del siglo XVII, la economía colonial de la provincia de Costa Rica entró en crisis debido a la catástrofe demográfica aborigen por causa de su sobreexplotación a partir de 1570 (Solórzano, 2000b). Esta crisis coincide con las descripciones que se hacían sobre nuestras ciudades, como la célebre que realizara Gaspar de Chinchilla planteada como una queja contra el gobernador don Juan de Ocón y Trillo, allá por el año de 1608: “...que Cartago [no] parecía ciudad de españoles sino estancia despoblada...” (Greñas, 1985). La situación económica de la provincia mejora a mediados del siglo XVII con la siembra masiva de cacao en Matina.

Las transcripciones aportadas en este trabajo, demuestran que como ocurre hoy día, nuestra 
sociedad fue impactada en diversos grados por la actividad sísmica y sus consecuencias. Pero también se observa que solamente los daños ocurridos en los templos y algunas casas gubernamentales, como edificios que albergaron a los cabildos fueron documentados, lo cual se explica por la importancia que tenían estos para la sociedad. En cuanto a la referencia de daños en casas particulares, solo se detallan los de $1715(¿$ ?) sobre los daños en las casas donde se encontraba fundada una capellanía; otro daño en 1727 ocurrido en una casa perteneciente a Baltasara de Pan y Agua destruida completamente en el terremoto de 1728 y otra vivienda sujeta a una capellanía que fue afectada en 1756. Como se observa, sin embargo, en estas casas reportadas con daños existían capellanías fundadas, lo cual era del interés del titular de la capellanía. Es claro que debieron afectarse más viviendas en los diversos terremotos recopilados, pero estos daños eran de escaso interés para el gobierno provincial y en particular para la Iglesia, por no tener fundadas capellanías. Pero también hay que indicar que posiblemente un buen número de los vecinos vivían en casas de madera con techos de paja o en una vivienda construida enteramente con este último material, lo cual las hacia poco susceptibles a los sismos.

Un aspecto que contribuyó a la poca documentación de los sismos acaecidos en la época colonial, fue que estos no trascendieron a otras esferas políticas fuera de la provincia, por la escasa importancia de ella en materia comercial y económica para el Reino de España. De estos solamente trascendió el daño en la Factoría de Tabacos, por ser en ese momento, a finales del siglo XVIII, la principal actividad económica de la provincia, en razón de que la Corona le asignó a Costa Rica el monopolio de la producción tabacalera. Con relación a la calidad de los edificios de la provincia de Costa Rica llama la atención una descripción de 1803 de la Aduana de la Garita:

“...y por cuanto se advirtió que en una culata de la casa asota [sic] con mucha fuerza el agua cuando llueve violentamente por el viento por cuya razón si no se repara esta parte puede venirse abajo la pared, y por consiguiente la casa, por ser esta de adobe cuyo material es de poca consistencia por ser de tierra, que con la continuación de humedecerse se desmorona..." (Archivo
General de Centro América, A3,13, Expediente 664, legajo 45, en: Peraldo y Montero, 1994)

Cabe resaltar que, a diferencia de otras provincias de la Capitanía, Costa Rica no tuvo que llorar muertes provocadas por el colapso de edificios debido a terremotos, lo que indica la baja vulnerabilidad de los habitantes de Costa Rica durante el período colonial.

Finalmente, aunque se han rescatado valiosos documentos que describen la ocurrencia de algunos sismos, la descripción de los efectos sobre las obras civiles son parcos, por lo que Peraldo \& Montero (1994) solo estimaron un valor de intensidad aproximado con base en las escuetas descripciones obtenidas en pocos edificios de las poblaciones afectadas. En la figura 1 se muestran las localidades que fueron afectadas y el nivel de intensidad estimado por Peraldo \& Montero (1994), asociado con los diversos terremotos documentados con información primaria en la época colonial. Las localidades afectadas se localizan a lo largo del valle Central del país, con excepción de Matina. También, es notaria la ausencia de sismos documentados en Nicoya, a pesar de la importancia que esta localidad tuvo durante la colonia y considerando además su ubicación directamente sobre la zona interplaca Coco-Caribe, donde ocurren eventos con magnitudes entre 7,0 y 7,5 cada 30 a 40 años. Adicionalmente, se puede observar que los terremotos documentados no se pudieron asociar con fuentes sísmicas determinadas. La posible excepción es el terremoto de Barva de 1772, que Peraldo \& Montero (1994) lo asocian con el sistema de falla de Alajuela.

Es importante enmarcar la ocurrencia de los sismos de finales del siglo XVIII e inicios del siglo XIX dentro de la convulsa historia de finales del periodo colonial. La provincia de Costa Rica, cubierta por un negro velo que representó los casi 250 años de vida colonial, se enfrenta a cambios que van a girar su destino en 180 grados. A fines del siglo XVIII, los acontecimientos en Europa tales como la revolución francesa que desata la independencia de los Estados Unidos en América del Norte y el avance del liberalismo positivista, hacen que tarde o temprano las colonias españolas americanas experimenten movimientos que buscan la libertad, y se alejen de un sistema monárquico enquistado en glorias pasadas y en una 
camarilla de personajes beatificados por el rancio abolengo y por la adulación a los Borbones.

En esa situación política, nos sorprende el ocaso del siglo XVIII y el nacimiento del XIX. Varios personajes llevarán ideas novedosas y representarán para sus respectivas regiones el definitivo cambio de estatus político. Es interesante que en ese ambiente político turbulento, la naturaleza se conjuga para, al menos en Costa Rica, aumentar los problemas que de por sí se avecinaban para la dormida provincia.

En primer lugar, a finales del siglo XVIII, a la ocurrencia de los sismos, que afectaron en diferente medida el mediocre desarrollo socioeconómico de la provincia, se unió la disposición de la Audiencia de Guatemala en 1791, de quitar a la empobrecida Costa Rica el derecho al monopolio del tabaco, y además se le prohibió sembrar tabaco hasta 1794 inclusive (Sáenz, 1994), lo que hizo disminuir los modestos ingresos de la provincia. Además, en 1800, una plaga de langostas afectó los tabacales del centro del valle central y como resultado, la producción de tabacos cae de 12,720 pesos en 1800 a 9365 en 1801. Costa Rica, gracias al monopolio del tabaco cosechaba 10000 quintales/año, pero después el nivel de producción bajó abruptamente, pues en 1810 cosechó 4000 quintales, en 1814, 400 quintales y en 1819, 1500 quintales (Sáenz, 1994). En ese marco económico ocurrió el sismo de abril de 1821 y al inicio de la época independiente el de mayo de 1822, que en conjunto afectaron de manera importante a la provincia de Costa Rica.

Para mayores males, el invierno provocaba serias inundaciones en Matina destruyendo los de por sí esmirriados campos de cacao tal como lo comenta Sáenz (1994). En 1802, por ejemplo, el déficit de Costa Rica se cuenta en miles de pesos, al punto que la Real Caja de Nicaragua aporta fondos para el mantenimiento de la administración de la provincia costarricense (Sáenz, 1994).

Por otro lado, La Corona, ávida de riquezas para mantenerse a flote, dispone de los fondos píos. Es así que en 1803 se confiscan los fondos de cofradía para hacer frente a la difícil situación de la Corona Española. En este caso, se deja entender que los mayordomos de fábrica, van a tener menos fondos para las reparaciones de templos y conventos. Como reflejo de ese estado de cosas, el déficit anual de la provincia supera los 12000 pesos en 1807 (Sáenz, 1994).

En 1812, a raíz de la constitución gaditana refrendada por las Cortes de Cádiz, se desarticula el orden político administrativo del Reino de Guatemala y persisten solamente dos provincias organizadas por medio de Diputaciones Provinciales; una de ellas, instaurada por el Presbítero Florencio del Castillo, incorpora a Nicaragua y Costa Rica, cuya sede era la ciudad de León de Nicaragua. Posiblemente, por razones de cantidad de habitantes y tamaño del territorio, le corresponde a Nicaragua cinco de los siete representantes o diputados y a Costa Rica solamente dos. Esto hace que los cabildeos sean siempre favorables a Nicaragua, lo que hace sumamente incómodo la labor de los diputados por Costa Rica. La fundación de esa figura política, hace que ya no se tomen las decisiones de importancia en el seno del Cabildo de Cartago, sino que se deba consultar a la Diputación Provincial todo lo relacionado a su desarrollo, obras públicas, fondos públicos y píos, educación, administración política, contrataciones de la hacienda, desarrollo industrial y agrícola, entre otros aspectos. Por ejemplo, con relación a lo anterior, el 9 de febrero de 1813 se solicitan los fondos a la Junta Superior de León para realizar reparaciones en las cárceles de San José, mientras tanto, se sugiere a los Síndicos Procuradores que “... hagan las reparaciones a su costa con carácter eso sí de reintegro para cuando haya fondos..." (Archivo Nacional, Municipal, número 453, folios $15 f$ a 16f.). Es evidente que con esas perspectivas, los Síndicos Procuradores difícilmente aportarían de su propio peculio para realizar reparaciones, aún cuando estos fueran generados por temblores. Posteriormente, otro documento encontrado en Archivo Nacional deja entrever 


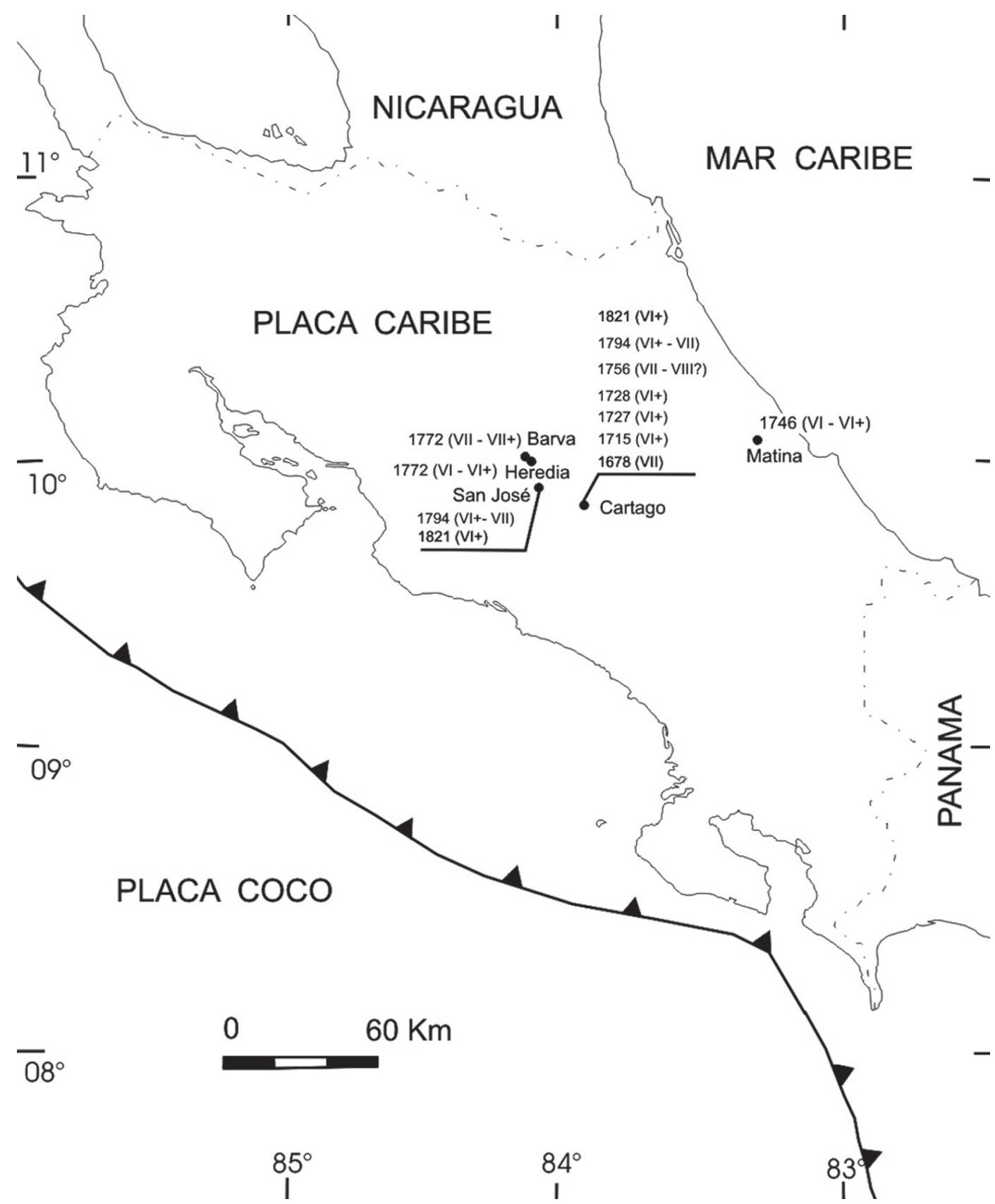

Fig. 1: Localidades afectadas por los terremotos ocurridos durante la colonia y niveles de intensidad estimados de acuerdo con Peraldo \& Montero (1994; 1999). Obsérvese la ausencia de daños documentados en Nicoya, una localidad importante durante la colonia. 
roces entre la Junta de Gobierno costarricense y la Junta de León, pues la referida nota que dirige el Ayuntamiento de Alajuela a la Junta de Gobierno de Costa Rica se indica que “... en vista de los oficios de la Exma Junta de quatro del corriente, en que incluye unas noticias de la ciudad de León por lo que se ven tratan de oprimir a esta ..."( Archivo Nacional de Costa Rica, Municipal, número 115, folio 10v, fecha de 7 de febrero de 1823, firmado en la Sala Capitular del Ayuntamiento de Alajuela). Estos supuestos roces, junto con la difícil situación política por los aires de independencia que corrían generaron fuertes incertidumbres que desembocaron en luchas internas, pudieron hacer más difícil las reparaciones que aún se llevaban a cabo como resultado de los daños ocurridos por el sismo de abril de 1821 y que no se habían reparado cuando sorprendió a los habitantes del centro de Costa Rica el gran sismo de San Estanislao del 7 de mayo de 1822 .

\section{REFERENCIAS}

AGUILAR, O.; 1997: Heredia, imágenes y tradiciones de antaño.- 273 págs. Ed. Progreso, San José.

BARRANTES, C., 2004: Orígenes de la diócesis de San Isidro de El General: Una historia eclesiástica regional 1522-1954.- 584 págs. Imprenta Nacional, San José.

GONZÁLEZ, C., 1910: Temblores, terremotos, erupciones volcánicas e inundaciones en Costa Rica, 1608-1910.- 200 págs. Imprenta Alsina, San José.

GREÑAS, R., 1984: Costa Rica en la época del gobernador don Juan de Ocón y Trillo.313 págs. Ed. Costa Rica, San José.

PERALDO, G. \& MONTERO, G.; 1994: Los temblores del periodo colonial de Costa Rica.- 162 págs. Ed. Tecnológica de Costa Rica, Cartago.
PERALDO, G., \& MONTERO, W., 1999: Sismología Histórica de América Central.347 págs. Instituto Panamericano de Geografía e Historia, Publ. No. 513, México D.F..

SAÉNZ C, J., 1994: Don Joaquín De Oreamuno y Muñoz de la Trinidad, vida de un monárquico costarricense.- 295 págs. Ed. Universidad Estatal a Distancia, San José.

SANABRIA, V. M., 1984: Reseña histórica de la Iglesia en Costa Rica, desde 1502 hasta 1850.- 290 págs. Departamento Ecuménico de Investigaciones, San José.

SOLÓRZANO, J. C., 2000a: Descubrimiento y conquista de Costa Rica 1502-1575. En: BOTEY, A. M., 2000: Costa Rica, desde las sociedades autóctonas hasta 1914. Editorial de la Universidad de Costa Rica, San José: 61-111.

SOLÓRZANO, J.C., 2000b: La sociedad colonial 1575-1821.- En: BOTEY, A. M., 2000: Costa Rica, desde las sociedad autóctonas hasta 1914. Editorial de la Universidad de Costa Rica, San José: 113-161.

THIEL, B., 1983: Datos cronológicos para la historia eclesiástica de Costa Rica.- 240 págs. Ministerio de Cultura, Juventud y Deportes, Comisión Nacional de Conmemoraciones Históricas, San José.

VELÁSQUEZ, C., 2005: Diccionario de términos coloniales.- 134 págs. Ed. Universidad de Costa Rica, San José.

\section{REFERENCIAS DE ARCHIVOS}

Archivo Nacional de Costa Rica, Cartago, No. 1143, folio 10.

Archivo Nacional de Costa Rica, Cartago, No. 1143 , folio 49. 
Archivo Eclesiástico de laCuria Metropolitana, Fondos Antiguos, Libros empastados, Libro de Cofradía de Nuestra Señora de Los Ángeles.

Archivo Eclesiástico de la Curia Metro-politana, Fondos Antiguos, Libros empastados, Caja 7, folio 296.
Archivo Eclesiástico de la Curia Metropo-litana, Fondos Antiguos, Libros empastados, Caja 15 , folios $444-446$. 